\title{
COMMONWEALTH
}

A Journal of Pennsylvania Politics and Policy

EDITOR-IN-CHIEF J. Wesley Leckrone, Widener University

MANAGING EDITOR Michelle J. Atherton, Temple University

ASSOCIATE EDITORS Christopher Borick, Muhlenberg College

Paula A. Duda Holoviak, Kutztown University

Joseph P. McLaughlin, Jr., Temple University

EDITORIAL ADVISORY

BOARD Bruce Caswell, Rowan University

Beverly A. Cigler, Pennsylvania State University, Harrisburg

Richardson Dilworth, Drexel University

John J. Kennedy, West Chester University

John Kincaid, Lafayette College

Joseph Marbach, Georgian Court University

David Y. Miller, University of Pittsburgh

Megan Mullin, Duke University

Richard A. Stafford, Carnegie Mellon University

COPY EDITOR Meredith Phillips

EDITORIAL ASSISTANT Jack Heavner, Widener University

FOUNDING EDITOR

EMERITUS Donald G. Tannenbaum, Gettysburg College

EDITORS EMERITUS Thomas J. Baldino, Wilkes University

Gerard J. Fitzpatrick, Ursinus College 


\section{The Pennsylvania Political Science Association}

ounded in 1939, the Pennsylvania Political Science Association (PPSA) is the nation's oldest state political science association. Its mission has always been to promote scholarship, research, and the exchange of ideas within the Pennsylvania community of political scientists. PPSA draws its membership principally from the political science and public administration faculties of Pennsylvania's public and private colleges and universities but also includes government professionals and faculty members from surrounding states.

PPSA's annual conference includes dozens of panelists covering a wide variety of subjects. While university faculty compose the vast majority of participants, legislators, legislative staff, executive officials, and undergraduates also have participated. For more information on the activities of PPSA and membership rates, please visit the Association's website at http://www.papolisci.org/. 
THE PENNSYLVANIA POLITICAL SCIENCE ASSOCIATION

OFFICERS AND EXECUTIVE COUNCIL

2019-2020

PRESIDENT

FIRST VICE PRESIDENT SECOND VICE PRESIDENT

A. Lanethea Mathews-Schultz

Michael Greenberg

Heather Frederick

Muhlenberg College

Shippensburg University

Slippery Rock University

TREASURER

Steven B. Lem

Kutztown University
SECRETARY

Paula A. Duda Holoviak

Kutztown University

EXECUTIVE COUNCIL

2017-2020

2018-2021

2019-2022

Michelle J. Atherton

Justin DePlato

Temple University

Robert Morris University

Jennie Sweet-Cushman

John Kennedy

Sarah Niebler

West Chester University

Dickinson College

Chatham College

Joshua Weikert

Immaculata University

\section{EX OFFICIO MEMBERS}

IMMEDIATE PAST PRESIDENT

Steven Peterson

Pennsylvania State

University, Harrisburg
PAST PRESIDENTS

Christopher Borick

Muhlenberg College

Stanley Berard

Lock Haven University
Brooke Harlowe

Lock Haven University

EDITORIAL STAFF OF COMMONWEALTH:

A Journal of Pennsylvania Politics and Policy

$\begin{array}{lll} & \text { EDITOR-IN-CHIEF } & \\ & \text { J. Wesley Leckrone } & \\ & \text { Widener University } & \\ \text { FOUNDING EDITOR EMERITUS } & \text { EDITORS EMERITUS } & \\ \begin{array}{l}\text { Donald G. Tannenbaum } \\ \text { Gettysburg College }\end{array} & \text { Thomas J. Baldino } & \text { Gerard J. Fitzpatrick } \\ & \text { Wilkes University } & \text { Ursinus College }\end{array}$




\section{Pennsylvania Policy Forum}

OMMONWEALTH collaborates with the Pennsylvania Policy Forum to plan special issues and attract high-quality content to the journal. The Forum is a consortium of faculty members and academic and policy institute leaders from Pennsylvania colleges and universities who share an interest in generating ideas, analyses, and symposiums that might prove useful to citizens, elected officials, and civic leaders in addressing major issues confronting the Commonwealth and its local governments. As educators who have helped train students for careers in public policy, members also share an interest in helping to improve the skills, knowledge, and tools of leaders in the public and civic sectors.

Members of the Forum have expertise in public policy analysis as well as a wide range of substantive issues, including but not limited to education, transportation and public infrastructure, economic development, agriculture, energy, elections, water policy and the environment, health care, social policy, urban development, emergency management, information technology, public finance, and constitutional law. Members also share an interest in improving both the policy process itself and the institutional structures through which issues and problems are addressed.

Forum members have contributed to public policy debates in Pennsylvania, and a number have also served in state and local government and in nonprofit and civic organizations that engage in policy development and implementation. Some members of the Forum are associated with other academic and public policy-related organizations, but the Forum itself is independent of these relationships and has no formal connections to any government entity. Members obviously benefit from the intellectual resources and environments of their universities, but unless otherwise indicated, they do not act on behalf of their institutions when they sponsor Forum projects. The premise of the Forum is that through the consortium, members can jointly develop and sponsor nonpartisan research, symposiums, and education and training programs of value to elected officials, civic leaders, and the public and thereby enhance their ability to contribute to more intelligent and informed policymaking. 


\section{PENNSYLVANIA POLICY FORUM MEMBERSHIP (2020)}

Theodore R. Alter, Pennsylvania State University

Michelle J. Atherton, Temple University

Thomas J. Baldino, Wilkes University

Vincent Cannizzaro, York College of Pennsylvania

Beverly A. Cigler, Pennsylvania State University, Harrisburg

Richardson Dilworth, Drexel University

Michael R. Dimino, Sr., Widener University Commonwealth Law School

(Chair) Paula A. Duda Holoviak, Kutztown University

Mark Alan Hughes, University of Pennsylvania

John J. Kennedy, West Chester University

John Kincaid, Lafayette College

Robin Lauermann, Messiah College

J. Wesley Leckrone, Widener University

(Vice Chair) Joseph P. McLaughlin, Jr., Temple University

David Y. Miller, University of Pittsburgh

Randall M. Miller, St. Joseph's University

Joseph Sabino Mistick, Duquesne University School of Law

Richard A. Stafford, Carnegie Mellon University

Craig Wheeland, Villanova University 


\section{Contents}

Volume 21, Number 1 | 2021 I ISSN 2469-7672

\section{EDITOR'S NOTE}

- Introduction to the Special Issue on Women in Pennsylvania Politics | Jennie Sweet-Cushman, Special Issue Editor

\section{ARTICLES}

- What Do Pennsylvania Voters Think about Gender and Women's Representation?: What We Learned from 2016 and 2018 Exit Polls | Sarah Niebler and A. Lanethea Mathews-Schultz

- Gendered Pathways to Power: Identifying the Role of County Party Chairs in the Candidate Recruitment Process of Pennsylvania's Local Elective Offices | Dana Brown

- Wave or Trend: Female Candidates in Pennsylvania Elections in the Trump Era | Joshua J. Weikert

- Solving Pennsylvania's Budget Woes: Increased Female Representation | Benjamin Melusky 